\section{Indirect laryngoscopic surgery for benign vocal fold lesions: a preliminary report}

Ognjen Cukic

Department of Otorhinolaryngology with Maxillofacial Surgery, Clinical Hospital Center Zemun, Belgrade, Serbia

\section{Abstract}

The current practice for removal of benign vocal fold lesions is microlaryngoscopy under general anaesthesia. The technique provides excellent magnification with use of operating microscope and enables the surgeon to work with both hands at the same time. However, in certain cases the technique of indirect laryngoscopic surgery under local epimucous anaesthesia can be used as an alternative. In this article we will give the brief historic perspective of the procedure, indications and technical description, as well as its advantages and limitations. Given the fact that technique is not widely accepted by otolaryngologists, the author will also share some personal remarks on this relatively simple procedure.

Keywords: vocal fold lesions, indirect laryngeal surgery, microlaryngoscopy, laryngeal neoplasms

\section{Indirektna laringoskopska hirurgija benignih lezija glasnih žica: preliminarno saopštenje}

\author{
Ognjen Čukić \\ ${ }^{1}$ Služba Otorinolaringologije sa maksilofacojalnom hirurgijom, Hirurška \\ klinika, KBC Zemun, Beograd, Srbija
}

\section{Apstrakt}

Aktuelna metoda za uklanjanje dobroćudnih lezija glasnica na našem odeljenju je mikrolaringoskopija u opštoj endotrahealnoj anesteziji. Ova tehnika obezbeđuje odlično uveličanje pomoću operacionog mikroskopa i omogućava hirurgu da istovremeno operiše sa obe ruke. Ipak, u nekim slučajevima se kao alternativa može koristiti i indirektna laringoskopska hirurgija u lokalnoj epimukoznoj anesteziji. U ovom članku ćemo napraviti kratak istorijski osvrt na proceduru, indikacije i opis same hirurške tehnike, kao i njene prednosti i ograničenja. Imajući u vidu da ova tehnika nije široko prihvaćena od strane otorinolaringologa, autor će navesti i neka lična zapažanja u vezi sa ovom relativno jednostavnom tehnikom.

Ključne reči: lezije glasnica, indirektna laringealna hirurgija, mikrolaringoskopija, laringealne neoplazme

\title{
Introduction
}

Benign vocal fold lesions (BVFL) are commonly seen in otolaryngologic practice. True benign tumours of the vocal folds, except papilloma, are rare. ${ }^{1}$ Pseudotumours of the vocal folds are much more frequently encountered in clinical practice and they usually appear secondary to the functional trauma to the vocal folds, chronic inflammation or combination of the two. ${ }^{2}$ Some of these lesions will favourably respond to conservative treatment, such as voice therapy, smoking cessation or anti reflux medications, but most of them will require some form of surgery. ${ }^{3}$ Various techniques are available at laryngologist's disposal, the one most used being the direct microlaryngoscopy in general anaesthesia. ${ }^{4,5}$ In selected patients, indirect laryngoscopic surgery in local anaesthesia can also be used.

\section{Materials and methods}

A total of 318 patients with BVFLs were treated surgically at Department of Otorhinolaryngology with Maxillofacial Surgery from January 2011 to June 2016. Three hundred and six patients were operated using the standard microlaryngoscopy in general anaesthesia, while twelve patients were operated using the indirect laryngoscopic technique in local anaesthesia. The distribution of pathology and the procedure used is shown in table 1. For removal of BVFLs in general anaesthesia, we use the laryngeal exposure as described by Kleinsasser ${ }^{4}$ and removal of vocal fold pathology using the microsurgical technique described by Bouchayer. ${ }^{5}$ After placing the smallest possible endotracheal tube by anaesthesiologist and positioning the patient's 
head in the so-called "sniffing" position (head extended on the neck, neck flexed on the body), the surgeon introduces the Kleinsasser's directoscope (Karl Storz) to the laryngeal inlet, directly exposing the glottis and the vocal fold pathology. Under the $25 x$ magnification provided by the operating microscope (Carl Zeiss Opton), the lesion is carefully grasped by straight micro-forceps (Karl Storz) through the directoscope and gently pulled medially in order to expose its attachment on the vocal fold, followed by complete excision using the tip-curved micro-scissors (Karl Storz). The patients to be operated by indirect laryngoscopic technique are seated as for routine otolaryngology examination. We use 10-percent lidocaine solution for anaesthetising the oropharynx, epiglottis with laryngeal inlet and vocal folds. We apply the anaesthetic by spraying the solution four to five times on ventral surface of tongue, soft palate and posterior wall of oropharynx each. We spray the larynx ten to fifteen times during the phonation, followed by additional application of the local anaesthetic by massaging the supraglottic $\mathrm{s}$ tructures with the curved cotton ball probe dipped in the anaesthetic solution (Fig. 1).

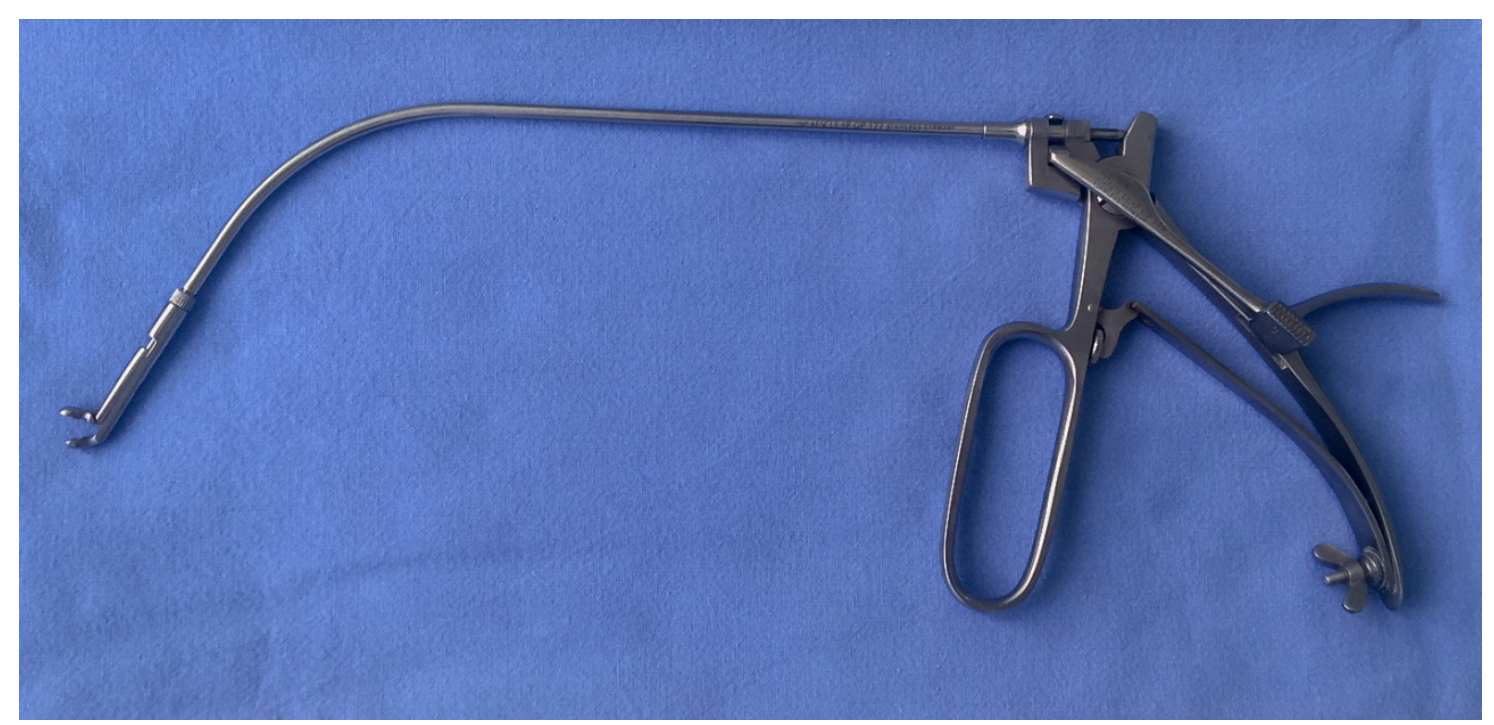

Figure 1. Brunnings curved cup forceps for indirect operations in larynx

Following the application of the local anaesthetic, the surgeon asks the patient to hold his/her own tongue with a piece of gauze, as for mirror laryngoscopy examination. The surgeon then simultaneously introduces the rigid 70- or 90-degree telelaryngoscope (Karl Storz ) with the non-dominant hand and the curved Brunnings cup forceps (Karl Storz) with the dominant hand in the patient's oropharynx (Fig. 2).

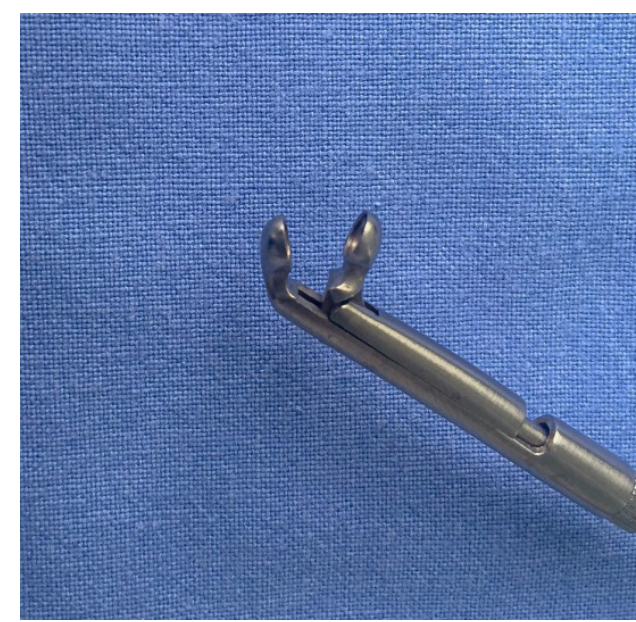

Figure 2. Interchangeable tip of the forceps magnified. 
Under the visual guidance, the surgeon advances the tip of the forceps towards the vocal fold lesion, grasps it and removes in a single anterior to posterior motion (Figure. 3), respecting the vocal fold histologic structure. ${ }^{6}$

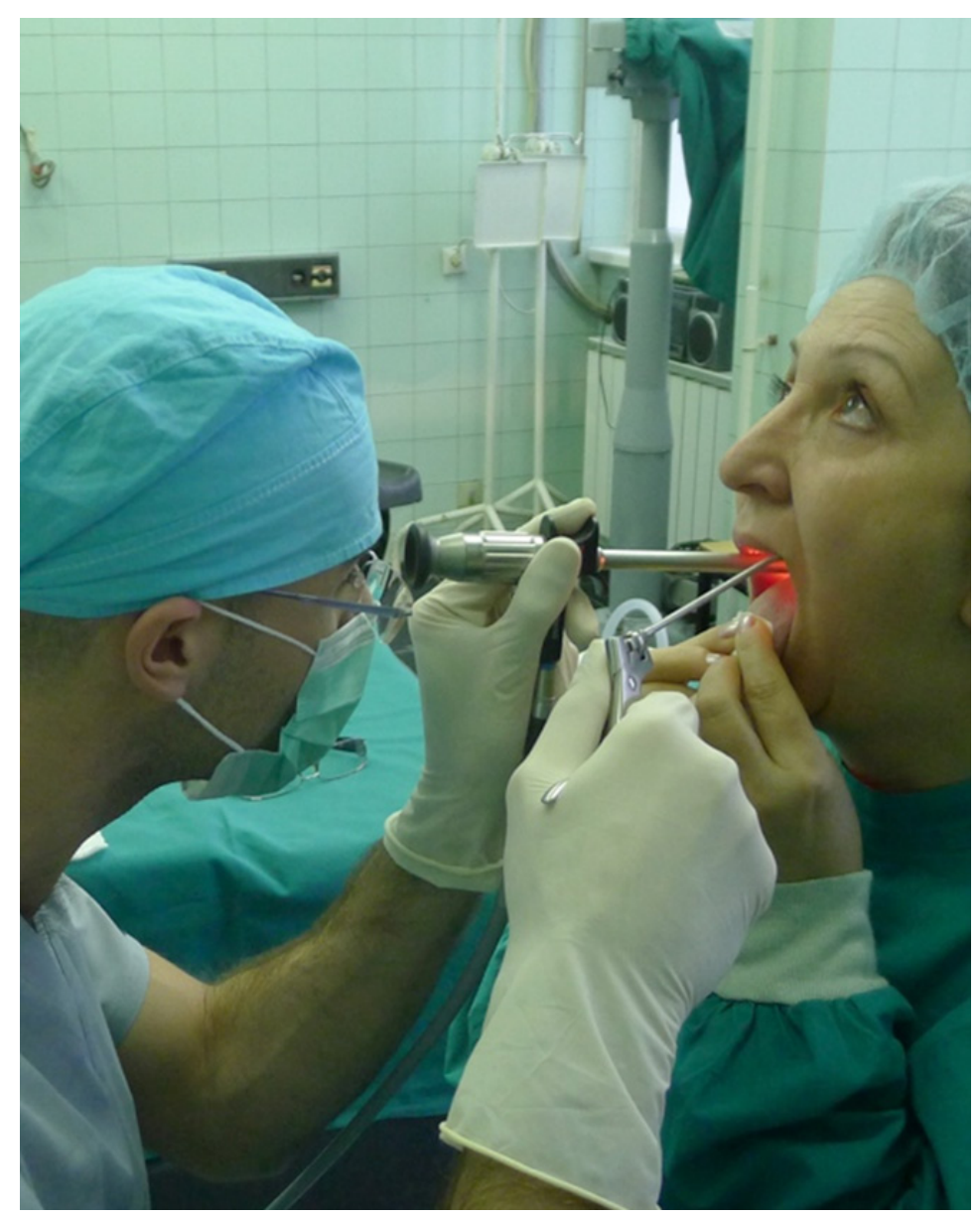

Figure 3. Position of the patient and surgeon during the procedure. Note the patient holding his/her own tongue while the surgeon introduces the rigid scope and Brunnings forceps.

The patients are discharged immediately after the operation, with nothing-by-mouth advice for the hour following surgery and voice rest instructions.

\section{Results}

We achieved optimal results using both surgical techniques. We operated various BVFLs using classic microlaryngoscopy technique, as shown in Table 1. We reserved indirect laryngoscopic surgery for smaller lesions which could be grasped and removed with single instrument (Figure 4.). 


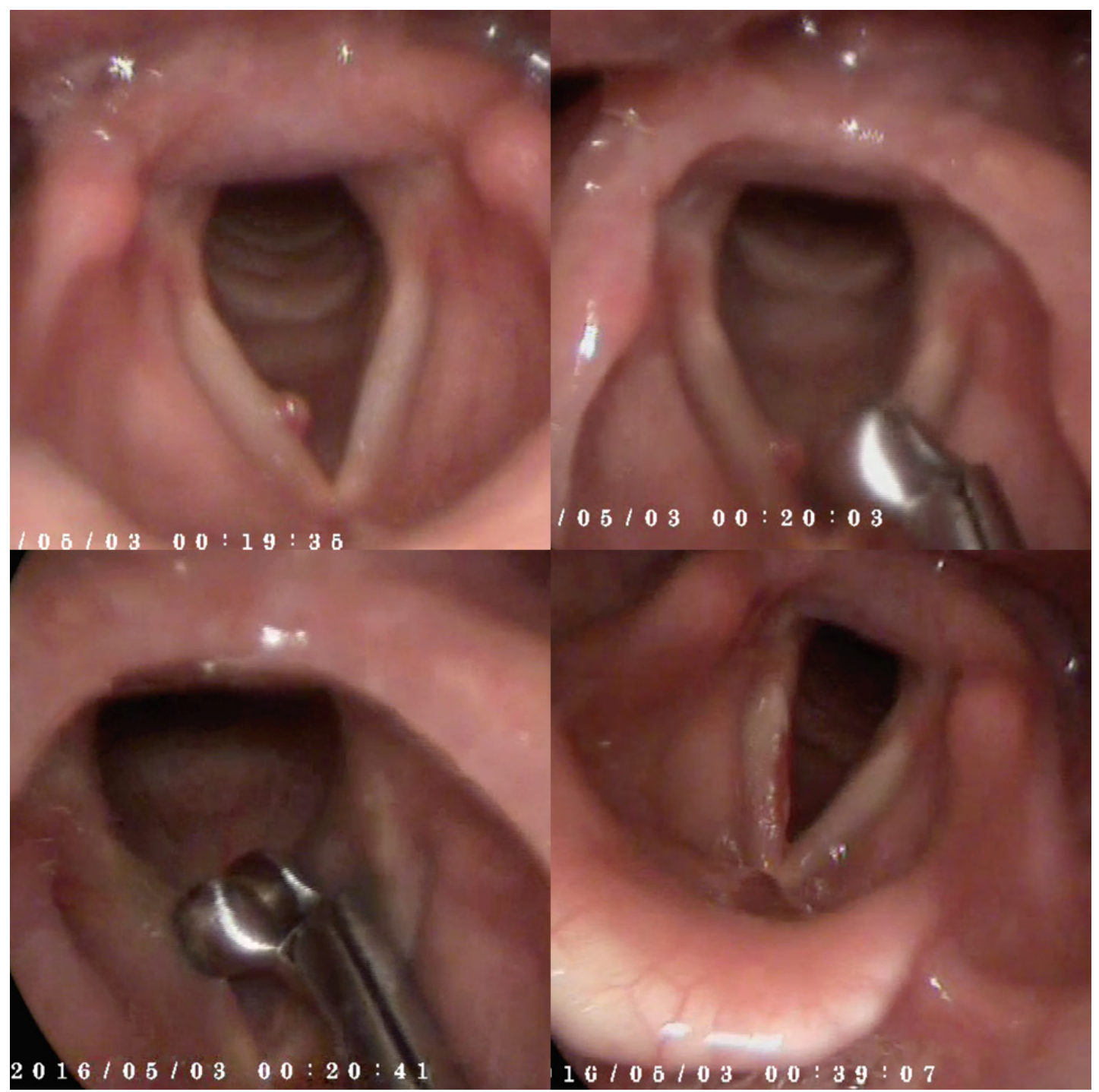

Figure 4. A - polyp of the right vocal fold (black arrow); B - introduction of the curved cup forceps into the laryngeal inlet; C - cup forceps gently grasping the polyp; D - right vocal fold after the polyp removal. Note the straight edge of the fold with no residual polyp tissue.

The improvement in voice quality was immediate and most apparent after operating the smaller lesions. The voice quality improved somewhat later in cases of diffuse, chronic oedemas, where complete epithelization of the larger surface of the vocal fold occurs several weeks after the operation. The relatively small number of the patients operated by indirect laryngoscopic technique is probably due to fact that most of these were performed during the author's residency and lack of his own outpatient clinic. The other reason might be the lack of subspecialised phoniatrics office in our centre, which would almost certainly provide larger load of patients with BVFLs. 


\begin{tabular}{|c|c|c|}
\hline Type of lesion & Microlaryngoscopy & Indirect laryngoscopy sugery \\
\hline Polyp & 147 & 12 \\
\hline Reinke' oedema & 145 & 0 \\
\hline Granuloma & 3 & 0 \\
\hline Vocal fold Cyst & 5 & 0 \\
\hline Nodules & 5 & 12 \\
\hline total & 306 & 0 \\
\hline
\end{tabular}

Table 1. Distribution of 318 patients operated for benign vocal fold lesions in CHC Zemun from January 2011 to June 2016.

However, the patients treated by indirect laryngoscopic surgery were satisfied with immediate voice improvement, short intervention time, no need for hospitalisation and workup for general anaesthesia. The complications were usually associated with the application of the topical anaesthetic. The patients reported a certain degree of anxiety and a "choking" sensation as a result of numbness of the throat. This is solved by simple verbal reassurance and instructing the patients to breathe through the nose, in order to convince them that there is no airway compromise. Two patients had excessive gagging even after the application of anaesthetic and were re-scheduled for the microlaryngoscopy.

\section{Discussion}

Benign vocal fold lesions represent a wide variety of laryngeal pathology and can be classified as true benign tumours and pseudotumours of the vocal folds. The benign tumours, except papilloma, are quite rare, and may be of epithelial (adenoma), mesenchymal (fibroma, leiomyoma, rhabdomyoma, lipoma, etc.), and neural origin (Schwannoma, paraganglioma, neurofibroma). ${ }^{1,2}$ Pseudotumours of the larynx are not true neoplasms, but represent lesions that arise secondary to functional trauma, chronic inflammation or specific infection. The may also be of metabolic origin. ${ }^{2}$ Their macroscopic and microlaryngoscopic appearance is similar to true benign tumours, and correct diagnosis is often obtained only after histopathologic examination. Unlike benign tumours which can only be cured surgically, pseudotumours may also respond favourably to conservative treatment. However, majority of these lesions will eventually require surgery. ${ }^{3}$ The variable degree of hoarseness is the common and most dominant symptom in BVFLs and the main reason for otolaryngology referral. Hoarseness is a result of difference in mass and tension of the two vocal folds, change of the mechanical characteristics of the affected vocal fold and glottal insufficiency. ${ }^{2}$ The degree of hoarseness and its influence on quality of life in patients can be measured using objective acoustic analysis in specialised voice labs, as well as self-assessment questionnaires. These analysis are related to subspecialist phoniatric units and are not routinely used.

Various types of surgical management of BVFLs have been described: microlaryngoscopy in general anaesthesia with cold instruments ${ }^{4,5}$ or $\mathrm{CO} 2$ laser, ${ }^{7,8}$ office-based excision in local anaesthesia using flexible fiberendoscope to deliver various lasers ${ }^{9}$ and indirect laryngoscopic surgery in local anaesthesia, using either mirror laryngoscopy in combination with the operating microscope,${ }^{10,11}$ or rigid tele laryngoscope with stroboscopic light source. ${ }^{12}$ The author used 90-degree rigid tele laryngoscope with cold light source, without stroboscopy. Microlaryngoscopy with cold instruments is considered as "a gold standard" in surgical management of BVFLs and is the preferred treatment at our department. However, the indirect technique in local anaesthesia can be used, when appropriate. There are advantages and limitations in both techniques, ${ }^{12}$ and some of them are outlined in Table 2. 


\begin{tabular}{|c|c|c|}
\hline & Microlaryngoscopy & Indirect laryngoscopy sugery \\
\hline magnification & + & + \\
\hline bimanual work & + & + \\
\hline $\begin{array}{c}\text { hospitalisation\&general } \\
\text { anaesthesia }\end{array}$ & + & + \\
\hline patient comfort & & + \\
\hline physiological setting & & + \\
\hline function monitoring & & + \\
\hline cost - effectiveness & & + \\
\hline
\end{tabular}

Table 2. Advantages and limitations of microlaryngoscopy and indirect laryngoscopic surgery.

Microlaryngoscopy in general anaesthesia provides excellent visualisation of the endolarynx and enables the surgeon to operate bimanually. This technique is optimal for removal of the bulky lesions (over 4 milimeters) with wide insertion. Microlaryngoscopy is also more suitable for submucosal lesions, which require careful microsurgical dissection and preservation of the overlying epithelium. We found indirect laryngoscopic surgery convenient for smaller lesions (less than 3 milimeters) and for lesions with narrow insertion which can be grasped and removed with single instrument. This technique also provides the surgeon an opportunity to assess the patient's voice during the surgery and to operate with the larynx in its physiological position. Surgical treatment outcomes can be evaluated by pre- and postoperative voice assessment. The literature on comparing treatment outcomes after microlaryngoscopy and indirect laryngoscopic surgery is sparse. $^{13}$

\section{Conclusion}

Although relatively technically simple, the indirect laryngoscopic surgery is not widely accepted in otolaryngologic practice. It is not a routine procedure and there is a lack of specific training during the residency. The author also observed the lack of interest for the procedure among the practitioners, as they are mostly trained and feel confident with the classic microlaryngoscopy in general anaesthesia. The technique is also not convenient for bulky and submucosal lesions and requires a certain degree of manual dexterity, as well as patient cooperation during the procedure, which is not always possible to achieve. However, the indirect phonosurgery under topical local anaesthesia is a valuable tool for removal of small benign vocal fold lesions and should be in armamentarium of every physician dealing with this kind of pathology, as a complementary procedure alongside conventional microlaryngoscopy. There is also a potential for future research, by comparing the voice improvement in both types of surgery, using subjective and objective voice analysis.

\section{References}

1. Mackenzie K. Chronic laryngitis. In: Gleeson M, Browning GG, Burton MJ, Clarke R, Hibbert J, Jones NS et al. (eds). Scott-Brown's Otorhinolaryngology, Head and Neck Surgery, 7th ed. London: Hodder Arnold; 2008:2258-70.

2. Milutinović Z. Klinički atlas poremećaja glasa - teorija i praksa. Beograd: Zavod za udžbenike i nastavna sredstva; 1997.

3. Zeitels SM, Healy GB. Laryngology and phonosurgery. N Engl J Med 2003;349:882-92.

4. Kleinsasser O. Mikrolaryngoskopie und Endolaryngeale Mikrochirurgie. Stuttgart: Auflage Schattauer-Verlag; 1968.

5. Bouchayer M, Cornut G. Microsurgical treatment of benign vocal fold lesions: indications, technique, results. Folia Phoniatr (Basel) 1992;44(3-4):155-84.

6. Hirano M. Morphological structure of the vocal cord as a vibrator and its variations. Folia Phoniatr (Basel) 1974;26(2):89-94. 
7. Grossenbacher R. CO2 laser surgery for benign lesions of the vocal cords. Adv Otorhinolaryngol 1995;49:158-61.

8. Benninger MS. Microdissection or microspot CO2 laser for limited vocal fold benign lesions: a prospective randomized trial. Laryngoscope 2000;110(2 Pt 2 Suppl 92):1-17.

9. Zeitels SM, Burns JA. Office-based laryngeal laser surgery with local anesthesia. Curr Opin Otolaryngol Head Neck Surg 2007;15(3):141-7.

10. Wendler J. Endolaryngeale Eingriffe in indirekter Mikroskopie ohne Zusatzoptik. HNO 1969;17:158-9.

11. Seidner W. Indirect micro-phonosurgery. Laryngorhinootologie 2000;79(11):673-4

12. Milutinović Z. Phonosurgical treatment of benign lesions of the vocal cords (10 years' experience). Srp Arh Celok Lek 1996;124(9-10):236-40.

13. Dikkers FG, Sulter AM. Suspension microlaryngoscopic surgery and indirect microlaryngostroboscopic surgery for benign lesions of the vocal folds. J Laryngol Otol 1994;108(12):1064-7.

Corresponding author:

Ognjen Čukić

Department of Otorhinolaryngology with Maxillofacial Surgery,

Clinical Hospital Center "Zemun-Beograd"

Vukova 9,

11080 Belgrade, Serbia

telephone: +381653016562

e-mail address: ognjen.cukic.bg@gmail.com 